\title{
Biochar Yield From Shell of Brazil Nut Fruit and Its Effects on Soil Acidity and Phosphorus Availability in Central Amazonian Yellow Oxisol
}

\author{
D. M. Oliveira ${ }^{1}$, N. P. S. Falcão ${ }^{1}$ J. B. D. Damaceno ${ }^{2} \&$ I. A. Guerrini ${ }^{3}$ \\ ${ }^{1}$ National Institute for Amazonian Research, Technology and Innovation Coordination, Manaus, Amazonas, \\ Brazil \\ 2 Tropical Agronomy Graduate Program, Amazonas Federal University, Manaus, Amazonas, Brazil \\ ${ }^{3}$ College of Agricultural Sciences, São Paulo State University, Botucatu, São Paulo, Brazil \\ Correspondence: D. M. Oliveira, National Institute for Amazonian Research, Technology and Innovation \\ Coordination, Manaus, Amazonas, Brazil. E-mail: dmoliveira.am@gmail.com
}

Received: August 19, 2019

Accepted: January 31, $2020 \quad$ Online Published: February 15, 2020

doi:10.5539/jas.v12n3p222

URL: https://doi.org/10.5539/jas.v12n3p222

\begin{abstract}
Phosphorus is one of the most limiting elements in the amazon soil, requiring low cost alternatives that increase the agronomic efficiency of phosphate fertilizers for satisfactory crop production and biochar has been used as an option for increase soil fertility. The objective of this work was to evaluate the yield and properties of the biochar produced from the shell of Brazil nut fruit at $500{ }^{\circ} \mathrm{C}$, as well as its behavior in the acidity and phosphorus availability from mineral source in Yellow Oxisol. The experimental design was completely randomized in a factorial arrangement $(5 \times 5)$ with five doses of biochar $\left(0,20,40,60\right.$ and $\left.80 \mathrm{tha}^{-1}\right)$ and five doses of $\mathrm{P}_{2} \mathrm{O}_{5}(0$, $100,200,300$ and $\left.400 \mathrm{~kg} \mathrm{ha}^{-1}\right)$ in $20 \mathrm{~kg}$ pots. The trial was carried out at 365 days and the yield and properties of the produced biochar were evaluated, as well as the determination of acidity and total and available phosphorus. The biochar produced from feedstock was considered satisfactory, with $59 \%$, which is a good alternative for producers. Aluminum contents were reduced confirming the potential of biochar as a corrective for acidity. Additionally, the amount of total and available phosphorus increased with increasing biochar doses. Thus, not only the feedstock but also the pyrolysis temperature showed hight potencial to improve the amount of phosphorus in the soil and decrease the soil acidity.
\end{abstract}

Keywords: soil fertility, pyrogenic carbon, perennial culture

\section{Introduction}

The Amazonian soils phosphorus fixation process is stronger than other Brazilian regions, due to the presence of large amounts of iron and aluminum oxides and hydroxides, kaolinite, which limit the crops production. Brazilian agriculture apply around of 15 million tons of P per year (Wang et al., 2012), of which only 5 to $20 \%$ is uptake by culture (Price, 2006). In addition, the estimated lifetime of the world's phosphorus reserves would be around 40 years (Streubel et al., 2012). These facts show the need to adopt strategies that increase available P and improve the agronomic efficiency of short term mineral fertilizers.

Peng et al. (2012), Streubel et al. (2012), and Yao et al. (2013b) demonstrated that biochar, besides being a source of $\mathrm{P}$, could be capable of adsorbing phosphate. This suggests its potential in maintaining the applied $\mathrm{P}$ as fertilizer. Recently studies showed that the use of biochar can increase soil phosphorus availability (Atkinson et al., 2011; Edelstein \& Tonjes, 2012; Farrell et al., 2014; Glaser et al., 2002; Gul et al., 2015; Sohi et al., 2010; Falcao et al., 2018; Glaser \& Lehr, 2019), in addition, the use of biocarbonised organic waste (biochar) can have its effect confirmed as a soil conditioner and as a plant nutrient source based on Amazonian Dark Earth studies.

In the Amazon, due to soil origin and intense rainfall, inconveniences with phosphate fertilization become even more critical, but the maintenance of high levels of phosphorus, calcium, magnesium, zinc and organic carbon in the Amazonian Dark Earth is associated to a large and prolonged input of fresh and biocarbonised organic material (pyrogenic carbon) (Glaser et al., 2001; Lehmann et al., 2002, 2003b). 
Thus, it is necessary to understand and rescue techniques that have been used by local Indians for centuries (Steiner et al., 2004), linking them with existing technologies such as mineral fertilizers. The practice of biocarbonization aims mainly at harnessing residues from agroindustrial activities with biochar production and its use in improving the physical, chemical and biological quality of degraded soils (Wang et al., 2012; Yuan et al., 2011a, 2011b). It also has a positive impact on reducing greenhouse gas (GHG) emissions by increasing carbon stocks in soils and improving agricultural production and recovery processes of degraded areas (Nóbrega, 2011). However, the levels of macro ( $\mathrm{P}, \mathrm{K}, \mathrm{Ca}$ and $\mathrm{Mg}$ ) and micronutrients ( $\mathrm{Mn}$ and $\mathrm{Zn}$ ) in the biochar composition are low, so the use of biochar in the soil requires additional nutrient sources to complement fertilization, increasing the agronomic efficiency of mineral and organic fertilizers, meeting the nutritional needs for growth and production of cultivated species (Falcao et al., 2018; Glaser \& Lehr, 2019). Thus, the objective of this work was evaluate the potential of Brazil nut bark biochar to increase the amounts of total and available phosphorus and also the decrease the acidity index in the Amazonian Oxisol.

\section{Material and Methods}

The experiment was conducted in a greenhouse at the National Institute Amazon for Research-INPA, Manaus, $\left(3^{\circ} 5^{\prime} 29^{\prime \prime} \mathrm{S}\right.$; 59 $\left.59^{\prime} 37^{\prime \prime} \mathrm{W}\right)$ Amazonas. The experimental design was completely randomized, in a factorial arrangement $(5 \times 5)$ with five levels of biochar $\left(0,20,40,60\right.$ and $\left.80 \mathrm{tha}^{-1}\right)$, produced under a temperature of 500 ${ }^{\circ} \mathrm{C}$ and five doses of $\mathrm{P}_{2} \mathrm{O}_{5}\left(0,100,200,300\right.$ and $\left.400 \mathrm{~kg} \mathrm{ha}^{-1}\right)$, been as source triple superphosphate with $41 \%$ of $\mathrm{P}_{2} \mathrm{O}_{5}$, totalizing 25 treatments, with 4 replications and 100 experimental units. A complementary fertilization with $400 \mathrm{Kg} \mathrm{ha}^{-1}$ of $\mathrm{N}$ as urea, $532 \mathrm{~kg} \mathrm{ha}^{-1}$ of $\mathrm{K}_{2} \mathrm{O}$ as $\mathrm{KCl}$ and $80 \mathrm{~kg} \mathrm{ha}^{-1}$ of micronutrients (FTE), all in a split form.

The soil used was a typical dystrophic Yellow Oxisol, clayey texture, collected from the 20-40 cm layer (Sombroek, 1966) with the following characteristics: $\mathrm{pH} \mathrm{CaCl}(3.60), \mathrm{Ca}^{2+}\left(6.00 \mathrm{mmol}_{\mathrm{c}} \mathrm{dm}^{-3}\right), \mathrm{Mg}^{2+}\left(2.00 \mathrm{mmol}_{\mathrm{c}}\right.$ $\left.\mathrm{dm}^{-3}\right), \mathrm{Al}^{3+}\left(9.00 \mathrm{mmol}_{\mathrm{c}} \mathrm{dm}^{-3}\right), \mathrm{H}+\mathrm{Al}\left(31.00 \mathrm{mmol}_{\mathrm{c}} \mathrm{dm}^{-3}\right) \mathrm{K}^{+}\left(1.33 \mathrm{mmol}_{\mathrm{c}} \mathrm{dm}^{-3}\right), \mathrm{CTC}(39.00), \mathrm{V} \%$ (22.00), P $\left(3.00 \mathrm{mg} \mathrm{dm}^{-3}\right)$, S $\left(47.00 \mathrm{mmol}_{\mathrm{c}} \mathrm{dm}^{-3}\right)$, Fe $\left(251.40 \mathrm{mg} \mathrm{dm}^{-3}\right), \mathrm{Zn}\left(1.13 \mathrm{mg} \mathrm{dm}^{-3}\right)$ and $\mathrm{Mn}\left(0.57 \mathrm{mg} \mathrm{dm}^{-3}\right)$ as determined by Resin method. The soil was passed through sieves with $2.00 \mathrm{~mm}$ diameter mesh and placed in 20 $\mathrm{L}$ plastic pots, filled with $20 \mathrm{~kg}$ of soil, and the treatments were all homogenized with biochar and mineral fertilizers.

The biochar was obtained from the biocarbonization of the dry biomass of the shell of Brazil nut fruit harvested in the 2014, in a retort located at the Forest Products Research Coordination of the National Institute for Amazon Research (CPPF-INPA). The biocarbonization was temperature of $500{ }^{\circ} \mathrm{C}$ reached after $2 \mathrm{~h} 30$ with residence time of 12 hours, the biochar was removed from retort after total cooling at room temperature, than was manually ground using a wood piece and passed through a $2 \mathrm{~mm}$ sieve.

The chemical characterization was done in order to obtain total contents of nutrients in the biochar, characteristics such as moisture and ash content were also determined, with biochar samples passed in a $1 \mathrm{~mm}$ sieve knife mill. To determine the humidity, a biochar mass was oven dried at $105^{\circ} \mathrm{C}$ for 24 hours and cooled in a desiccator at room temperature. The samples were weighed and calculated according to the equation 1 :

$$
\mathrm{U}=(\text { dry } \mathrm{M}) /(\text { wet }) \times 100
$$

The ashes contents was determined in a muffle (QUIMIS), with residence time of 3.5 hours, then weighed in analytical balance and the calculation of ashes performed as presented in the equation 2:

$$
\% \text { ashes }=[(\mathrm{D}-\mathrm{B}) /(\mathrm{C}-\mathrm{B})] \times 100
$$

Where, $\mathrm{B}=$ mass of calcined crucible $(\mathrm{g}) ; \mathrm{C}=$ mass of crucible with initial sample on dry basis $(\mathrm{g})$; $\mathrm{D}=$ mass of ash crucible $(\mathrm{g})$.

The soil was collected twelfth month after the trial installation, been three single samples per pot, making up one compost sample, than put to dry environmental temperature, than a sieved in a $2.00 \mathrm{~mm}$ mesh sieve an than conducted to the soil laboratory for the following determinations: $\mathrm{pH}\left(\mathrm{CaCl}_{2}\right)$ at ratio 1:2.5 (soil:solution) (Raij et

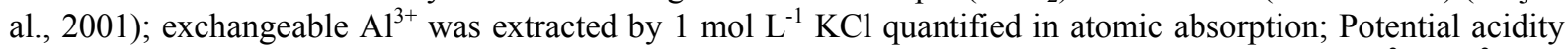
$(\mathrm{H}+\mathrm{Al})$ was determined by the SMP buffer method (Shoemaker, McLean, \& Pratt, 1961), and $\mathrm{Ca}^{2+}, \mathrm{Mg}^{2+}$ and available phosphorus (P) were extracted by ion exchange resin and determined by colorimetry (Raij et al., 2001). Total phosphorus was extracted according to the method proposed by Hedley et al. (1982), with some modifications proposed by Codron et al. (1985) and ICP reading. 
The results were analyzing by variance analyses (ANOVA) and subsequent regression analysis aiming to adjust the equations to the data obtained as a function of doses for each treatments. It was adopted as criterion in the choice of the model the interaction by the significant test $\mathrm{F}$ at $5 \%$ and $1 \%$, with the aid of the $\mathrm{R}$ statistical program (R Core Team 2018).

\section{Results and Discussion}

The biocarbonization of the shell of Brazil nut fruit produced 59\% for biochar, 33\% for pyroligneous acid and $2 \%$ for tar. In general, most of the feedstock materials used for biochar production yield a maximum of $40 \%$, depending on the temperature and the lignin content that is proportional to the yield. The high yield of biochar shows that this raw material has great potential for use not only by producers, but also by the traditional population living on extractivism, thus avoiding the disposal of this material in areas that may contribute to the proliferation of insect vectors of various tropical diseases.

Galinatto et al. (2011) assessing the economic potential of biochar in winter wheat crop, from production and use as soil conditioner to carbon stock estimates, concluded that depending on the market price of the product, biochar may be profitable and may yet, enter the carbon offset market.

The ash content of the shell of Brazil nut fruit biochar and the moisture content were $2.9 \%$ and $6.0 \%$, respectively. According to Demeyer et al. (2001) and Barros (2006) a good biochar should be in a range of 3\% and $4 \%$ ash and less than $8 \%$ humidity, demonstrating that the characteristics obtained here are with the average value within the proper range. Adsorption capacity due to low ash content can be positively influenced due to volatilization of organic material (Ramos et al., 2009; Cisnero and Gonzáles, 2010).

According to Cruz Júnior (2010), the basic ash composition of shell of Brazil nut fruit is of $\mathrm{K}_{2} \mathrm{O}(30.8 \%), \mathrm{CaO}$ (17.1\%), $\mathrm{SiO}_{2}(15.6 \%), \mathrm{Fe}_{2} \mathrm{O}_{3}(13.6 \%), \mathrm{S}, \mathrm{P}, \mathrm{Mg}, \mathrm{Al}, \mathrm{Na}, \mathrm{Mn}, \mathrm{Ti}, \mathrm{Cl}, \mathrm{Ni}$ and some metals in low contents. Table 1 shows the chemical attributes of biochar from Brazil nuts bark at a temperature of $500{ }^{\circ} \mathrm{C}$. We can observe by the chemical characteristics presented that this material should not be considered a source of fertilizer, but a conditioner of the soil, since when used alone, it influences much more in the soil structure, improving water retention, aeration, root system growth and soil biological activity. Lehmann et al. (2003b) and Van Zwieten, et al. (2010), attributed the higher plant growth to the positive changes in soil biogeochemistry resulting from biochar additions. However, Glaser and Lehr (2019), mentioned that biochar can be considered a source of phosphorus to low fertility soils.

Table 1. Chemical characteristics of the chestnut urchin biochar produced at $500^{\circ} \mathrm{C}$

\begin{tabular}{llllllllllllll}
\hline Material & $\mathrm{pH}$ & $\mathrm{N}$ & $\mathrm{P}$ & $\mathrm{K}$ & $\mathrm{Ca}$ & $\mathrm{Mg}$ & $\mathrm{S}$ & $\mathrm{B}$ & $\mathrm{Cu}$ & $\mathrm{Fe}$ & $\mathrm{Mn}$ & $\mathrm{Zn}$ & $\mathrm{Na}$ \\
\hline & $\mathrm{CaCl}_{2}$ & $--------------\mathrm{g} \mathrm{kg}^{-1}-------------$ & ------------ & $\mathrm{mg} \mathrm{kg}^{-1}--------------$ \\
Biochar $500{ }^{\circ} \mathrm{C}$ & 9.1 & 7.0 & 0.6 & 23.0 & 6.0 & 2.4 & 1.4 & 41 & 28 & 575 & 264 & 25 & 159 \\
\hline
\end{tabular}

In general, as higher the pyrolysis temperature, as higher the $\mathrm{pH}$, ash content, carbon stability, biochar aromaticity, porosity and specific surface area (Wu et al., 2012; Zhao et al., 2013; Zhang et al., 2015b). Ringer et al. (2006) report that under slow pyrolysis conditions the yield is about $35 \%$ biochar, $30 \%$ bio-oil (pyroligneous acid and tar) and 35\% gas and Wright et al. (2010) describe lower yields of biochar in rapid pyrolysis compared to slow pyrolysis, as it generates about $15 \%$ biochar, $70 \%$ bio-oil and $13 \%$ gas.

Based the reference the total $\mathrm{N}$ content found in organic compounds, the value found in the biochar used in this work was considered "low", as well as the concentrations of $\mathrm{P}, \mathrm{Ca}, \mathrm{K}$ and $\mathrm{Mg}$, however, these are strongly influenced by temperature, the temperature increase also provides the increase of trace elements that are present as $\mathrm{Fe}, \mathrm{Cu} \mathrm{Mn}, \mathrm{Zn}$ and $\mathrm{Cd}$, however the bioavailability for the plant is very low and these concentrations are decreased with increasing temperature by changing their chemical forms during the process, however, $\mathrm{Fe}$ and Mn concentrations were elevated.

The nutritional characteristics of biochar vary depending on the material used in pyrolysis, but in most cases there is an increase in $\mathrm{pH}, \mathrm{CTC}$, macro and micronutrient contents (Hossain et al., 2011; Jeffery et al., 2011; Agrafioti et al., 2013; Yuan et al., 2013; Masek et al., 2013).

Similarly, very different responses to growth of different crops have been found for sugarcane bagasse biochar and biosolids (Chen et al., 2010). Based on the results observed in the present study, they emphasize the importance of quantifying the yield of biochars made from different raw materials before large-scale application. 


\subsection{Effect of Treatments on Acidity, Available and Total P Contents}

The results revealed that there was interaction between the doses of biochar and phosphate fertilization $(\mathrm{p}<$ 0.05 ), for $\mathrm{pH}$ values in $\mathrm{CaCl}_{2}$, with an increase of $1.44 \mathrm{pH}$ units, when comparing treatments without biochar and $80 \mathrm{tha}^{-1}$ both in the absence of $\mathrm{P}_{2} \mathrm{O}_{5}$ (Table 2). Van Zwiten et al. (2010) assessing the effect of biochar on acidic soils in Australia found that applying only biochar increased soil $\mathrm{pH}$ considerably, while treatment that received biochar and mineral fertilizer decreased soil $\mathrm{pH}$.

Table 2. Effect of different doses of biochar and $\mathrm{P}_{2} \mathrm{O}_{5}$ in Yellow Oxisol on $\mathrm{pH}\left(\mathrm{CaCl}_{2}\right)$ at 365 days after the installation of the experiment

\begin{tabular}{llllll}
\hline \multirow{2}{*}{$\mathrm{P}_{2} \mathrm{O}_{5}\left(\mathrm{~kg} \mathrm{ha}^{-1}\right)$} & \multicolumn{5}{c}{ Biochar t ha $^{-1}$} \\
\cline { 2 - 6 } & 0 & 20 & 40 & 60 & 80 \\
\hline 0 & $3.55 \mathrm{Ac}$ & $3.53 \mathrm{Ac}$ & $3.76 \mathrm{Abc}$ & $4.27 \mathrm{Ab}$ & $4.99 \mathrm{Aa}$ \\
100 & $3.46 \mathrm{Ac}$ & $3.45 \mathrm{Ac}$ & $3.84 \mathrm{Abc}$ & $4.33 \mathrm{Aab}$ & $4.75 \mathrm{Aba}$ \\
200 & $3.45 \mathrm{Ac}$ & $3.48 \mathrm{Ac}$ & $4.08 \mathrm{Ab}$ & $4.58 \mathrm{Ab}$ & $5.32 \mathrm{ABCa}$ \\
300 & $3.40 \mathrm{Ab}$ & $3.51 \mathrm{Ab}$ & $3.73 \mathrm{Ab}$ & $4.71 \mathrm{Aa}$ & $4.72 \mathrm{BCa}$ \\
400 & $3.42 \mathrm{Ac}$ & $3.47 \mathrm{Ac}$ & $4.11 \mathrm{Ab}$ & $4.74 \mathrm{Aa}$ & $4.34 \mathrm{Cab}$ \\
\hline
\end{tabular}

Note. Averages followed by the same lowercase letters in horizontal do not differ statistically from each other. Averages followed by the same capital letters in vertical do not differ statistically from each other.

In this experiment, it was also noted that treatments without biochar showed a slight acidification with increasing doses of $\mathrm{P}_{2} \mathrm{O}_{5}$, decreasing by $0.13 \mathrm{pH}$ units. Agreeing with Solaiman et al. (2012), who evaluated the effects of biochar applied to soils under different management systems, observed that in the treatment that received biochar with NPK fertilizer, the soil $\mathrm{pH}$ increased in relation to the control treatment, and those treatments that received only NPK the $\mathrm{pH}$ decreased in the corn, cowpea and peanuts crops.

The $\mathrm{pH}$ values increased considerably in the treatment that received $40 \mathrm{tha}^{-1}$ of biochar, this results may be explained by the high biochar adsorption capacity, since the temperature of $500{ }^{\circ} \mathrm{C}$ has a high surface area and a more condensed carbon structure. (Downie et al., 2009), which may have facilitated the retention of cations such as $\mathrm{Al}^{3+}$ and $\mathrm{Fe}^{2+}$.

In general, the doses of biochar presented a linear effect on the $\mathrm{pH}$ values, however, considering the ideal $\mathrm{pH}$ range for soil fertility, it can be seen that the doses from $40 \mathrm{t} \mathrm{ha}^{-1}$ of biochar independent of the $\mathrm{P}_{2} \mathrm{O}_{5}$ doses provided more adequate values, not only for plant nutrient availability but also in economic terms, since, from the $100 \mathrm{~kg} \mathrm{ha}^{-1}$ doses of $\mathrm{P}_{2} \mathrm{O}_{5}$, the variation of values was minimal.

Jeffery et al. (2011) in a review of the effects of biochar on soil, concluded that such practice provides a gain in crop yield, regardless of the type of feedstock and the amount of application, with an average increase of about $10 \%$ and attributed this gain. The contribution of biochar in increasing $\mathrm{pH}$, water retention capacity and nutrient availability.

These $\mathrm{pH}$ values are a reflection of the process of neutralization of exchangeable aluminium. According to Raij (2011), aluminium the main element that is associated with the negative effect of soil acidity on plants. In Brazil, the use of limestone to increase $\mathrm{pH}$ values is common, however, Caires et al. (2008), reports that this may have limited action since it is not promoting effect of acidity reduction in the subsurpeficial layers, which are dependent on the carbonate leaching process. In on other hand, the present study the limestone was not applied and the process of neutralizing exchangeable acidity was attributed to biochar. These results corroborate with Van Zwiten et al. (2010) and Berek et al. (2011) that in a field experiment installed on Hawaii's acid soils using 3.0 levels of biochar $(0,2.5$ and 5\%) cultivating Desmodium ovalifolium reported a decrease in Al content from 1.4 to $0.6 \mathrm{cmol}_{\mathrm{c}} \mathrm{kg}$. Similar results was found (Figure 1) in this study when increased the levels of biochar the exchangeable $\mathrm{Al}$ decreased in all treatments.

Although for the $\mathrm{Al}$ contents, there was no significant effect among the studied factors, it can be observed that the application of biochar, started the process of neutralization of $\mathrm{Al}$ at the first applied dose and was reduced as the doses increased biochar, (Figure 1)which allows us to infer about the power of biochar as an acidity corrector, this results may be occurred due to its ash content or physical characteristics, which makes it a great ally in the $\mathrm{pH}$ change processes. Malavolta et al. (2006) reports that high levels of Al impair the development of the root 
system and reduce the availability of nutrients such as $\mathrm{P}$ and $\mathrm{S}$, making biochar a promising material in reducing such inconveniences.

The application of $80 \mathrm{t} \mathrm{ha}^{-1}$ of biochar reduced the Al content in soil by over $90 \%$, which may be linked to the amount of ash present in the biochar (2.9\%) which represents a "good" indicator of agronomic use.
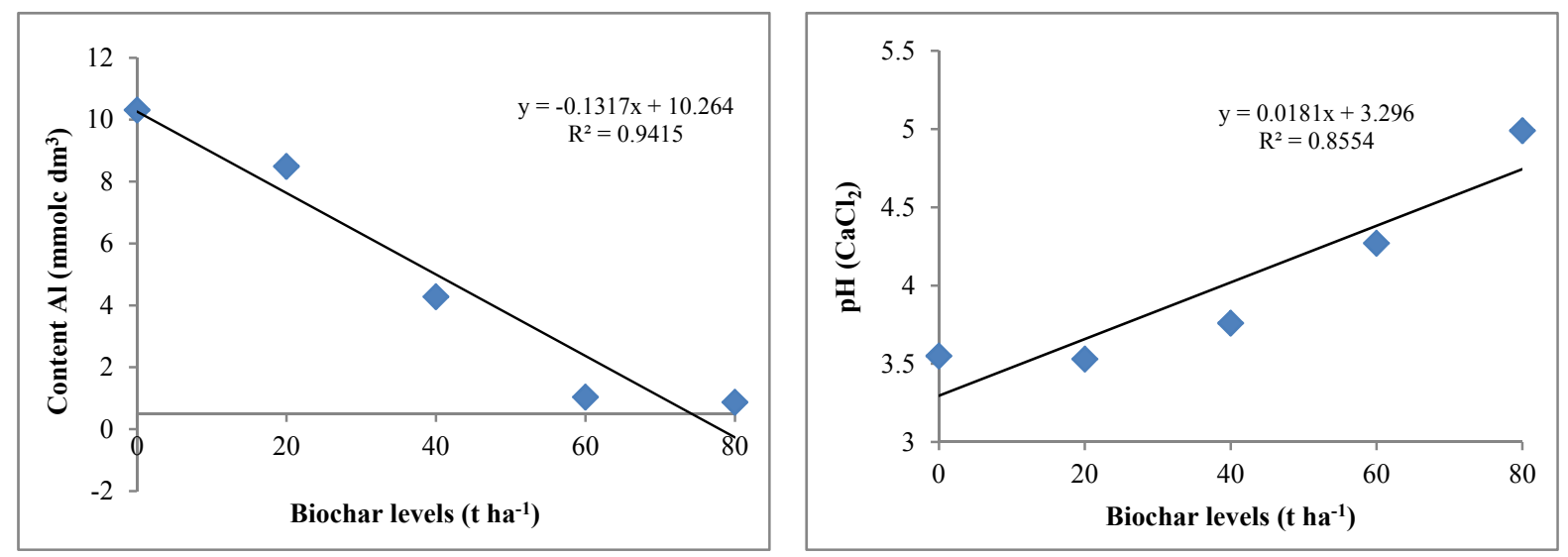

Figure 1. Acidity indices as a function of biochar levels after 365 days of application

Similar to $\mathrm{Al}^{3+}$ contents, $\mathrm{H}+\mathrm{Al}$ contents were strongly influenced by biochar application. The application of $60 \mathrm{t}$ $\mathrm{ha}^{-1}$ of biochar provided potential acidity reduction by approximately $50 \%$ (Figure 2 ).

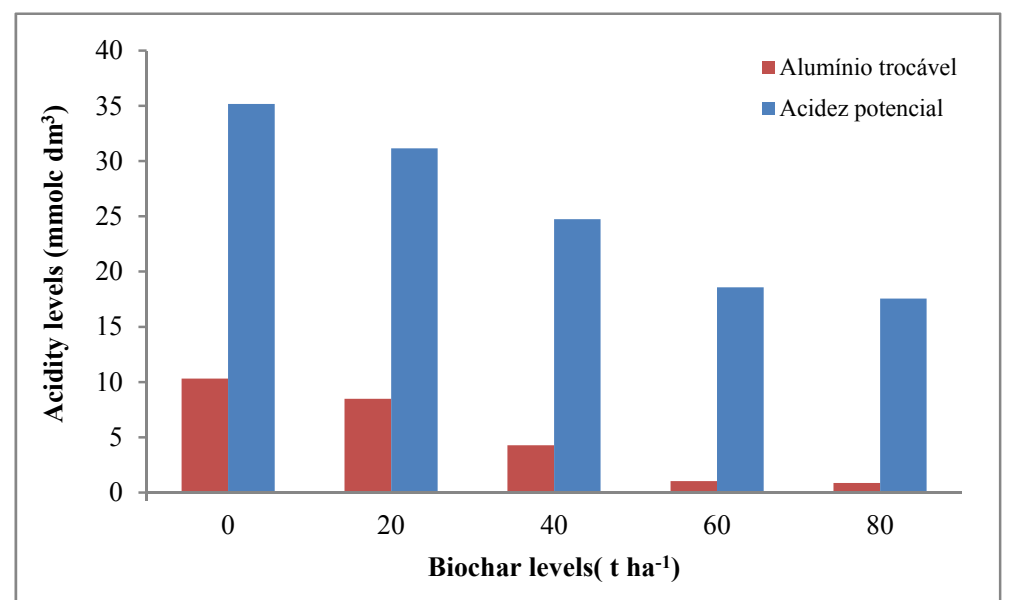

Figure 2. Exchangeable aluminum content and potential acidity 365 days after application of biochar levels

\subsection{Available and Total Soil Phosphorus Content}

The treatments resulted in significant differences in the phosphorus contents, being more pronounced between the doses of $\mathrm{P}_{2} \mathrm{O}_{5}$ applied. However, there was a considerable increase among treatments that received $400 \mathrm{~kg}$

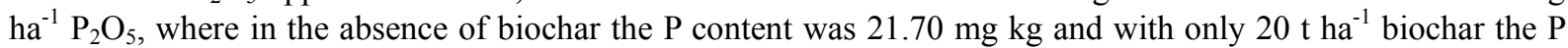
was 38.77 , which was statistically equal to the other biochar levels.

Coal samples taken from different black earth sites and at different depths showed different $\mathrm{P}$ adsorption and desorption properties (Falcão et al., 2003). These results allowed us to infer that this coal has the potential to retain significant amounts of solubilized P from mineral fertilizers, thus avoiding its chemical fixation by iron and aluminum oxides and type 1:1 clay present in high concentrations in tropical soils. 
Table 3. Effect of different doses of biochar and $\mathrm{P}_{2} \mathrm{O}_{5}$ in Yellow Oxisol on Phosphorus contents available 365 days after the installation of the experiment

\begin{tabular}{llllll}
\hline \multirow{2}{*}{$\mathrm{P}_{2} \mathrm{O}_{5}\left(\mathrm{~kg} \mathrm{ha}^{-1}\right)$} & \multicolumn{5}{c}{ Biochar $\left(\mathrm{t} \mathrm{ha}^{-1}\right)$} \\
\cline { 2 - 6 } & 0 & 20 & 40 & 60 & 80 \\
\hline 0 & $2 . .44 \mathrm{C}$ & $2.17 \mathrm{D}$ & $2.48 \mathrm{D}$ & $2.56 \mathrm{C}$ & $2.68 \mathrm{~B}$ \\
100 & $8.57 \mathrm{BC}$ & $9.68 \mathrm{CD}$ & $7.91 \mathrm{CD}$ & $6.70 \mathrm{C}$ & $6.58 \mathrm{~B}$ \\
200 & $19.71 \mathrm{Abab}$ & $16.46 \mathrm{BCab}$ & $16.75 \mathrm{BCab}$ & $14.19 \mathrm{BCb}$ & $28.27 \mathrm{Aa}$ \\
300 & $24.47 \mathrm{~A}$ & $25.22 \mathrm{~B}$ & $22.81 \mathrm{~B}$ & $21.19 \mathrm{~B}$ & $25.14 \mathrm{~A}$ \\
400 & $21.70 \mathrm{Ab}$ & $38.77 \mathrm{Aa}$ & $41.55 \mathrm{Aa}$ & $35.78 \mathrm{Aa}$ & $32.19 \mathrm{Aab}$ \\
\hline
\end{tabular}

Note. Averages followed by the same lowercase letters in horizontal do not differ statistically from each other. Averages followed by the same capital letters in vertical do not differ statistically from each other.

With the application of $\mathrm{P}_{2} \mathrm{O}_{5}$ doses without biochar, a significant increase up to $300 \mathrm{~kg} \mathrm{ha}^{-1} \mathrm{P}_{2} \mathrm{O}_{5}$ dose was observed, but the application of $20 \mathrm{t}$ of biochar the increase was linear until the maximum dose of $\mathrm{P}_{2} \mathrm{O}_{5}$. The levels of phosphorus decreased when $40 \mathrm{t}$ of biochar was applied, which may be linked to the increase in $\mathrm{pH}$, leading to the increase of available micronutrient contents in the soil solution and thus forming insoluble compounds such as Fe phosphate and Mn phosphate, the higher the amount of biochar, the greater the adsorption effect of P. However, Nelson et al. (2011) and Qayyum et al. (2015), reported that the application of 5,0 t of biochar temporarily reduced the available $\mathrm{P}$ content in two soil types, but in Oxisol did not significantly affect the availability of $\mathrm{P}$ with extra amounts of $\mathrm{P}$ was applied.

Since approximately $75 \%$ of $\mathrm{P}$ applied to Brazilian soils, as soluble phosphate fertilizer, is sorbed on the colloidal soil particles resulting in a low agronomic efficiency of this element (Raij, 2011), the presence of biochar may represent an "ally" in the soil cost reduction process in phosphate fertilizer.

Oliveira et al. (2019), working with bamboo biochar under different temperatures and different phosphate sources, reports that the P levels were higher in the treatment with biochar $\left(500^{\circ} \mathrm{C}\right)$ and triple superphosphate, in a rotation of 4 successive cycles, also allowing the observation of a longer effect of this soluble source

It is also noted that $\mathrm{P}$ levels, regardless of $\mathrm{P}_{2} \mathrm{O}_{5}$ levels, were affected by the presence of biochar, which may be associated with $\mathrm{P}$ sorption capacity by biochar, and may play an important role in the sorption and desorption of $\mathrm{P}$ in the process soil, acting as a more efficient $\mathrm{P}$ adsorbent per gram of material than soil clay fractions. Rajapaksha et al. (2015) reported that the presence of biochar in the soil resulted in increased $\mathrm{pH}, \mathrm{CTC}$ and P content.

These results may also be related to the characteristics of biochar, since pyrolysis performed at high temperature generally produces biochars with high surface area ( $>400 \mathrm{~m}^{2} / \mathrm{g}$ ) (Downie et al., 2009; Keiluweit et al., 2010), highly aromatic and consequently very recalcitrant to decomposition (Signh et al., 2010), and is considered good adsorbent (Mizuta et al., 2004; Lima \& Marshall, 2005), of cationic and anionic charges (Morales et al., 2013).

The reasons for the high efficiency of pyrogenic carbon in nutrient retention are: (a) biochar has a larger specific surface than coal resulting from burning wood at higher temperatures and (b) has a higher negative charge density per unit area consequently a higher charge density (Liang et al., 2014). This high charge density may, in principle, cause greater oxidation of the pyrogenic carbon itself or by non-pyrogenic carbon adsorption (Lehmann et al., 2005).

Although no significant difference was observed, in the absence of $\mathrm{P}$, the treatments that received $80 \mathrm{tha}^{-1}$ of biochar showed a slight increase compared to the control. Comparing the control treatment with that received 40 $\mathrm{t}$ of biochar in the absence of $\mathrm{P}_{2} \mathrm{O}_{5}$ and the treatment that received $40 \mathrm{t}$ of biochar with $100 \mathrm{~kg}$ of $\mathrm{P}_{2} \mathrm{O}_{5}$, we can see a highly significant increase in soil available P content, with a variation from 2.44 to 2.48 jumping to 7.91 , going from a range "very low or low" to "medium", considering ideal levels according to Raij (2011). In an economic aspect, it can be noted that the lower amount of $\mathrm{P}_{2} \mathrm{O}_{5}$ may be more efficient in the availability of $\mathrm{P}$.

The total phosphorus contents increased as increased the levels of biochar independent of the amounts of $P$ applied. A big part of this P liberated from different sources of fertilizer was, probably, linked to formations with $\mathrm{Fe}$ and Al. It is also observed that only the application of $80 \mathrm{t} \mathrm{ha}^{-1}$ of biochar, the amount of $\mathrm{P}$ increased by approximately $500 \%$, and it can be inferred that biochar can be considered a source of total P (Table 4).

In Brazilian soils, Guerra et al. (1996), and Cunha et al. (2007) found a variation of 13 to $47 \%$ of the total P occurring in the form of Po and Duda (2000) reports from 7 to $83 \%$, and this variation may be, according to 
these authors, related to the contents of $\mathrm{C}$ and total soil phosphorus. Wang et al. (2012) describe that some raw materials and carbonization temperatures, between $250{ }^{\circ} \mathrm{C}$ and $550{ }^{\circ} \mathrm{C}$, and which have high ash content generate high carbon content with higher $\mathrm{P}$ content and larger element recoverability, thus may be potential sources of $\mathrm{P}$ with high agronomic efficiency.

Table 4. Effect of different doses of biochar and $\mathrm{P}_{2} \mathrm{O}_{5}$ in Yellow Oxisol on total Phosphorus contents 365 days after the installation of the experiment

\begin{tabular}{llllll}
\hline $\mathrm{P}_{2} \mathrm{O}_{5}\left(\mathrm{~kg} \mathrm{ha}^{-1}\right)$ & 0 & 20 & 40 & 60 & 80 \\
\hline 0 & $7.02 \mathrm{Bb}$ & $9.25 \mathrm{Db}$ & $15.10 \mathrm{Dab}$ & $23.00 \mathrm{Dab}$ & $34.6 \mathrm{Ba}$ \\
100 & $27.10 \mathrm{~B}$ & $32.87 \mathrm{C}$ & $37.55 \mathrm{C}$ & $40.97 \mathrm{CD}$ & $38.45 \mathrm{~B}$ \\
200 & $57.32 \mathrm{Ab}$ & $54.15 \mathrm{BCb}$ & $58.60 \mathrm{BCb}$ & $62.45 \mathrm{BCab}$ & $80.87 \mathrm{Aa}$ \\
300 & $64.72 \mathrm{~A}$ & $69.30 \mathrm{AB}$ & $73.30 \mathrm{~B}$ & $79.55 \mathrm{~B}$ & $82.82 \mathrm{~A}$ \\
400 & $62.32 \mathrm{Ad}$ & $89.40 \mathrm{Ac}$ & $122.47 \mathrm{Aa}$ & $112.55 \mathrm{Aab}$ & $97.27 \mathrm{Abc}$ \\
\hline
\end{tabular}

Note. Averages followed by the same lowercase letters in horizontal do not differ statistically from each other. Averages followed by the same capital letters in vertical do not differ statistically from each other.

When comparing the available phosphorus and total phosphorus contents, as a function of the biochar doses, it is observed that for the total phosphorus, there was a significant increase even the material with $\mathrm{P}$ contents $(0.6 \mathrm{~g}$ $\mathrm{Kg}$ ), and $5.1 \mathrm{mg} \mathrm{kg}$. Wang et al. (2013), showed that the effect of P availability by biochar can be influenced by the $\mathrm{P}$ content present in the material, however, it is available $\mathrm{P}$, which in this experiment showed a slight increase.

Chintala et al. (2014) also found that $\mathrm{P}$ adsorption in biochar was significantly $(\mathrm{p}<0.0001)$ affected by the initial concentration of $\mathrm{P}$ and biochar type. These results indicate that not all biochars can be used to increase retention of $\mathrm{P}$ fertilizers in soils. However, biochar's ability to increase P retention in soils is quite variable and varies with $\mathrm{P}$ concentration in the soil solution.

Jorio et al. (2012), report that in black earth coal grains were found, through microscopy techniques, P contents at the edges of the material, showing inert internal structure, similar to graphite external structure with some nutrients such as $\mathrm{Ca}, \mathrm{P}$ and $\mathrm{Al}$.

\section{Conclusion}

The biochar produced from shell of Brazil nut fruit presented high yield for biochar production.

The biochar produced from shell of Brazil nut fruit showed high potential to corrective action and also as a source of total phosphorus.

The increase of biochar levels promoted the increase of availability of phosphorus from mineral sources.

\section{References}

Agrafioti, E., Bouras, G., Kalderis, D., \& Diamadopoulos, E. (2013). Biochar production by sewage sludge pyrolysis. Journal of Analytical and Applied Pyrolysis, 101, 72-78. https://doi.org/10.1016/j.jaap. 2013.02.010

Atkinson, C. J., Fitzgerald, J. D., \& Hipps, N. A. (2011). Potential mechanisms for achieving agricultural benefits from biochar application to temperate soils: A review. Plant Soil, 337(1-2), 1-18. https://doi.org/ 10.1007/s11104-010-0464-5

Barros, S. V. S. (2006). Avaliação da biomassa de espécies exóticas e nativas como fonte alternativa para geração de energia (Dissertação de Mestrado, UFAM, Manaus, AM).

Berek, A. K., Hue, N., \& Ahmad, A. (2011). Beneficial use of biochar to correct soil acidity. The Food Provider, September-November, 1-3. Retrieved from https://www.ctahr.hawaii.edu/huen/nvh/biochar.pdf

Caires, E. F., Banzatto, D. A., \& Fonseca, A. F. da. (2000). Calagem na superfície em sistema plantio direto. Revista Brasileira de Ciência do Solo, 24, 161-169. https://doi.org/10.1590/S0100-06832000000100018 
Caires, E. F., Barth, G., Garbuio, F. J., \& Churka, S. (2008). Effects of soil acidity amelioration by surface liming on no-till corn, soybean, and wheat root growth and yield. European Journal of Agronomy, 28(1), 57-64. https://doi.org/10.1590/S0103-90162008000500013

Chintala, R., Schumacher, T. E., McDonald, L. M., Clay, D. E., Papiernik, S. K., Clay, S. A., \& Julson, J. L. (2014). Phosphorus sorption and availability from biochars and soil/biochar mixtures. Clean-Soil, Air, Water, 42, 626-634. https://doi.org/10.1002/clen.201300089

Cisneros, C. M. A., \& González, M. P. E. (2010). Characterization of Manihot and preparation of activation carbon. Biomass and Bioenergy, 34(3), 389-395. https://doi.org/10.1016/j.biombioe.2009.12.001

Condron, L. M., Goh, K. M., \& Newman, R. H. (1985). Nature and distribution of soil phosphorus as revealed by a sequential extraction method followed by $\mathrm{P}^{31}$ nuclear magnetic resonance analysis. J. Soil Sci., 36, 199-207. https://doi.org/10.1111/j.1365-2389.1985.tb00324.x

Demeyer, A., Nkana, J. C. V., \& Verloo, M. G. (2001). Characteristics of wood ash and influence on soil properties and nutrient uptake: An overview. Bioresource Technology, 77, 287-295. https://oi.org/10.1016/ S0960-8524(00)00043-2

Downie, A., Crosky, A., \& Munroe, P. (2009). Physical properties of biochar. In J. Lehmann \& S. Joseph (Eds.), Biochar for environmental management. Science and technology (1st ed.). London: Earthscan. Retrieved from https://www.researchgate.net/publication/313661809_Physical_properties_of_biochar

Edelstein, D. M., \& Tonjes, D. J. (2012). Modeling an improvement in phosphorus utilisation in tropical agriculture. J Sustain Agr, 36, 18-35. https://doi.org/10.1080/10440046.2011.627993

Falcão, N. P. S., Comerford, N., \& Lehmann, J. (2003). Determining Nutrient Bioavailability of Amazonian Dark Earth Solis-Methodological Challenges. In J. Lehmann, D. Kern, B. Glaser, \& W. Woods (Eds.), Amazonian Dark Earths. Springer Netherlands.

Farrell, M., Macdonald, M. L., Butler, G., Chirino-Valle, I., \& Condron, L. M. (2014). Biochar and fertiliser applications influence phosphorus fractionation and wheat yield. Biol. Fertil. Soils, 50, 169-178. https://doi.org/10.1007/s00374-013-0845-z

Galinatto, S. P., Jonathan, K. J., \& Granatstein, D. (2011). The economic value of biochar in crop production and carbon sequestration. Energy Policy, 39, 6344-6350. https://doi.org/10.1016/j.enpol.2011.07.035

Glaser, B., \& Lehr, V. (2019). Biochar efects on phosphorus availability in agricultural soils: A meta-analysis. Scientific Reports, 9, 9338. https://doi.org/10.1038/s41598-019-45693-z

Glaser, B., \& Woods, W. I. (2004). Amazonian Dark Earths: Explorations in Space and Time. Berlin: Springer. https://doi.org/10.1007/978-3-662-05683-7

Glaser, B., Haumaier, L., Guggenberger, G., \& Zech, W. (2002). The “Terra Preta" phenomenon: A model for sustainable agriculture in the humid tropics. Naturwissenschaften, 88(1), 37-41. https://doi.org/10.1007/ s001140000193

Glaser, B., Lehmann, J., \& Zech, W. (2002). Ameliorating physical and chemical properties of highly weathered soils in the tropics with charcoal-A review. Biology and Fertility of Soils, 35(4), 219-230. https://doi.org/ 10.1007/s00374-002-0466-4

Gul, S., Whalen, J. K., Thomas, B. W., Sachdeva, V., \& Deng, H. Y. (2015). Physico-chemical properties and microbial responses in biocharamended soils: Mechanisms and future directions. Agriculture, Ecosystems and Environment, 206, 46-59. https://doi.org/10.1016/j.agee.2015.03.015

Hedley, M. J., Stewart, J. W. B., \& Chauhan, B. S. (1982). Changes in inorganic and organic soil phosphorus fractions induced by cultivation practices and by laboratory incubations. Soil Sci. Soc. Am. J., 46, 970-976. https://doi.org/10.2136/sssaj1982.03615995004600050017x

Hossain, M. K., Strezov, V., Chan, K. Y., Ziolkowski, A., \& Nelson, P. F. (2011). Influence of pyrolysis temperature on production and nutrient properties of wastewater sludge biochar. Journal of Environmental Management, 92, 223-228. https://doi.org/10.1016/j.jenvman.2010.09.008

Jeffery, L. S., Verheijen, F. G. A., Van Der Velde, M., \& Bastos, A. C. (2011). A quantitative review of the effects of biochar application to soils on crop productivity using meta-analysis. Agriculture, Ecosystems and Environment, 144, 175-187. https://doi.org/10.1016/j.agee.2011.08.015 
Jorio, A., Ribeiro-Soares, J., Cançado, L. G., Falcao, N. P. S., Dos Santos, H. F., Baptista, D. L. \& Achete, C. A. (2012) Microscopy and spectroscopy analysis of carbon nanostructures in highly fertile Amazonian anthrosoils. Soil and Tillage Research, 122, 61-66. https://doi.org/10.1016/j.still.2012.02.009

Keiluweit, M., Nico, P. S., Johnson, M. G., \& Kleber, M. (2010). Dynamic molecular structure of plant biomass-derived black carbon (biochar). Environmental Science \& Technology, 44, 1247-1253. https://doi.org/10.1021/es9031419

Lehmann, U., Martineau, T., Dieleman, M., Lexombooon, D., \& Matwa, P. (2005). The staffing of remote rural health services in low-income countries: A literature review of issues and options affecting attraction and retention. BMC Health Serv Res, 8, 19. https://doi.org/10.1186/1472-6963-8-19

Liang, X.-Q., Ji, Y. J., He, M.-M., Su, M.-M., Liu, C., \& Tian, G.-M. (2014) .Simple N balance assessment for optimizing the biochar amendment level in paddy soils. Commun. Soil Sci. Plant Anal., 45, 1247-1258. https://doi.org/10.1080/00103624.2013.875192

Lima, I. M., \& Marshall, W. E. (2005). Granular activated carbons from broiler manure: Physical, chemical and adsorptive properties. Biores. Tecnol., 96, 699-706. https://doi.org/10.1016/j.biortech.2004.06.021

Malavolta, E. (2006). Manual de nutrição mineral de plantas (p. 638). São Paulo, Ceres. Retrieved from https://bdpi.usp.br/item/001625739

Malavolta, E., Vitti, G. C., \& Oliveira, S. A. (1997). Avaliação do estado nutricional das plantas: Princípios e aplicações (2n ed., p. 319). Piracicaba, Potafos.

Masek, O., Brownsort, P., Cross, A., \& Sohi, S. (2013). Influence of production conditions on the yield and environmental stability of biochar. Fuel, 103, 151-155. 10.1016/j.fuel.2011.08.044

Mizuta, K., Matsumoto, T., Hatate, Y., Nishihara, K., \& Nakanishi, T. (2004). Removal of nitrate-nitrogen from drinking water using bamboo powder charcoal. Bioresource Technology, 95, 255-257. https://doi.org/ 10.1016/j.biortech.2004.02.015

Monterumici, C., Rosso, D., Montoneri, E., Ginepro, M., Baglieri, A., Novotny, E., ... Negre, M. (2015). Processed vs. non-processed biowastes for agriculture: effects of post-harvest tomato plants and biochar on radish growth, chlorophyll content and protein production. Int J Mol Sci, 16, 8826-8843. https://doi.org/10.3390/ijms16048826

Morales, M. M., Comerford, N., Guerrini, I. A., Falcão, N. P. S., \& Reeves, J. B. (2013). Sorption and desorption of phosphate on biochar and biochar-soil mixtures. Soil Use and Management, 29(3), $306-314$. https://doi.org/10.1111/sum.12047

Nelson, N., Agudelo, S., Yuan, W., \& Gan, J. (2011). Nitrogen and Phosphorus Availability in Biochar-Amended Soils. Soil Science, 176, 218-226. https://doi.org/10.1097/SS.0b013e3182171 eac

Nóbrega, Í. P. C. (2011). Efeitos do biochar nas propriedades fisicas e químicas do solo: Sequestro de carbono no solo (46f., Mestrado Dissertação, Instituto Superior de Agronomia, Universidade Técnica de Lisboa, Lisboa).

Oliveira, D. M., Damaceno, J. B. D., Lobato, A. C. N., Lavres, J. J., Guerrini, I. A., \& Falcão, N. P. S. (2019). Biochar of Bamboo Influencing the Availability of $\mathrm{P}$ from Different Phosphate Sources in Dystrophic Yellow Oxisol of Amazon. Journal of Agricultural Science, 11(9), 242. https://doi.org/10.5539/jas. $\mathrm{v} 11 \mathrm{n} 9 \mathrm{p} 242$

Peng, F., He, P. W., Luo, Y., Lu, X., Liang, Y., \& Fu, J. (2012). Adsorption of phosphate by biomass char deriving from fast pyrolysis of biomass waste. Clean: Soil Air Water, 40(5), 493-498. https://doi.org/10.1002/ clen.201100469

Price, G. (2006). Australian Soil Fertility Manual (3rd ed.). CSIRO Pub, Collingwood, Victoria.

Qayyum, M. F., Ashraf, I., Abid, M., \& Steffens, D. (2015). Effect of biochar, lime, and compost application on phosphorus adsorption in a ferralsol. J. Plant Nutr. Soil Sci., 178, 576-581. https://doi.org/10.1002/jpln. 201400552

Qian, K., Kumar, A., Zhang, H., Bellmer, D., \& Huhnke, R. (2015). Recent advances in utilization of biochar. Renew. Sustain. Energy Rev., 42, 1055-1064. https://doi.org/10.1016/j.rser.2014.10.074

Raij, B. V. (2011). Correção do solo. In B. van Raij (Ed.), Fertilidade do solo e manejo de nutrientes (pp. 352-375). Piracicaba: IPNI. 
Rajapaksha, A. U., Vithanage, M., Ahmad, M., Seo, D. C., Cho, J. S., Lee, S. E., .. Ok, Y. S. (2015). Enhanced sulfamethazine removal by steam-activated invasive plant-derived biochar. J. Hazard Mater, 290, 43-50. https://doi.org/10.1016/j.jhazmat.2015.02.046

Ringer, M., Putsche, V., \& Schahil, J. (2006). Large-scale pyrolysis oil production: A technology, assessment and economy analysis. National Renewable Energy Laboratory, NREL/TP-510-37779. https://doi.org/10.2172/ 894989

Shoemaker, H. E., Mclean, E. O., \& Pratt, P. F. (1961). Buffer methods for determining lime requirements of soils with appreciable amounts of extractable aluminum. Soil Sci. Soc. Amer. Proc., 25, $274-277$. https://doi.org/10.2136/sssaj1961.03615995002500040014x

Singh, B. P., Hatton, B. J., Singh, B., Cowie, A. L., \& Kathuria, A. (2010). Influence of biochars on nitrous oxide emission and nitrogen leaching from two contrasting soils. Journal of Environmental Quality, 39, 1-12. https://doi.org/10.2134/jeq2009.0138

Solaiman, Z. M., Murphy, D. V., \& Abbott, L. K. (2012). Biochars influence seed germination and early growth of seedlings. Plant Soil, 353, 273-287. https://doi.org/10.1007/s11104-011-1031-4

Sombroek, W. G. (1966). Amazon Soils-A reconnaissance of the soils of the Brazilian Amazon region. Center for Agriculture Publications and Documentation Wageningen, PUDOC.

Steinbeiss, S., Gleixner, G., \& Antonietti, M. (2009). Effect of biochar amendment on soil carbon balance and soil microbial activity. Soil Biology \& Biochemistry, 41(6), 1301-1310. https://doi.org/10.1016/j.soilbio. 2009.03.016

Steiner, C., Teixeira, W. G., Lehmann, J., \& Zech, W. (2004). Microbial response to charcoal amendments of highly weathered soils and Amazonian dark earths in Central Amazonia-preliminary results. In B. Glaser, \& W. I. Woods (Eds.), Amazonian dark earths: explorations in space and time (pp. 195-212). New York: Springer. https://doi.org/10.1007/978-3-662-05683-7_15

Streubel, J. D., Collins, H. P., Tarara, J. M., \& Cochran, R. L. (2012). Biochar produced from anaerobically digested fiber reduces phosphorus in dairy lagoons J. Environ. Qual., 41(4), 1166-1174. https://doi.org/ $10.2134 /$ jeq2011.0131

Van Zwieten, L., Kimber, S., Morris, S., Chan, K. Y., Downie, A., \& Joseph, J. S. (2010). Effects of biochar from slow pyrolysis of papermill waste on agronomic performance and soil fertility. Plant and Soil, 327, 235-246. https://doi.org/10.1007/s11104-009-0050-x

Wang, T., Arbestain, M. C., Hedley, M., \& Bishop, P. (2012). Predicting phosphorus bioavailability from high-ash biochars. Plant Soil, 357, 173-187. https://doi.org/10.1007/s11104-012-1131-9

Wang, T., Camps Arbestain, M., Hedley, M., \& Bishop, P. (2013). Chemical and bioassay characterisation of nitrogen availability in biochar produced from dairy manure and biosolids. Organic Geochemistry, 51, 45-54. https://doi.org/10.1016/j.orggeochem.2012.07.009

Wright, M. M., Daugaard, D. E., Satrio, J. A., \& Brown, R. C. (2010). Techno-economic analysis of biomass fast pyrolysis to transportation fuels. Fuel, 89(1), S2-S10. https://doi.org/10.2172/993332

Wu, D., Pan, B., Wu, M., Peng, H., Zhang, D., \& Xing, B. (2012). Coadsorption of Cu and sulfamethoxazole on hydroxylized and graphitized carbon nanotubes. Sci Total Environ, 427, 247-252. https://doi.org/10.1016/ j.scitotenv.2012.03.039

Yamato, M., Okimori, Y., Wibowo, I. F., Anshori, S. E., \& Ogawa, M. (2012). Effects of the application of charred bark of Acacia mangium on the yield of maize, cowpea and peanut, and soil chemical properties in South Sumatra, Indonesia. Soil Science an Plant Nutrition, 52(4), 489-495. https://doi.org/10.1111/ j.1747-0765.2006.00065.x

Yao, Y., Gao, B., Chen, J. J., Zhang, M., Inyang, M., Li, Y. C., ... Yang, L. Y. (2013). Engineered carbon (biochar) prepared by direct pyrolysis of $\mathrm{Mg}$-accumulated tomato tissues: Characterization and phosphate removal potential. Bioresour. Technol., 138, 8-13. https://doi.org/10.1016/j.biortech.2013.03.057

Yuan, H., Lu, T., Zhao, D., Huang, H., Noriyuki, K., \& Chen, Y. (2013). Influence of temperature on product distribution and biochar properties by municipal sludge pyrolysis. Journal Material Cycles Waste Management, 15, 375-361, https://doi.org/10.1021/jf104206c 
Yuan, J. H., Xu, R. K., Qian, W., \& Wang, R. H. (2011a). Comparison of the ameliorating effects on an acidic ultisol between four crop straws and their biochars. J. Soils Sediments, 11, 741-750. https://doi.org/ 10.1007/s11368-011-0365-0

Zhang, A., Liu, Y., Pan, G., Hussain, Q., Li, L., Zheng, J., \& Zhang, X. (2011). Effect of biochar amendment on maize yield and greenhouse gas emissions from a soil organic carbon poor calcareous loamy soil from Central China Plain. Plant and Soil, 351, 263-275. https://doi.org/10.1007/s11104-011-0957-x

Zhang, J., Liu, J., \& Liu, R. (2015a). Effects of pyrolysis temperature and heating time on biochar obtained from the pyrolysis of straw and lignosulfonate. Biores Technol, 176, 288-91. https://doi.org/10.1016/j.biortech. 2014.11.011

Zhao, L., Cao, X., Mašek, O., \& Zimmerman, A. (2013). Heterogeneity of biochar properties as a function of feedstock sources and production temperatures. J Hazard Mater, 256-57, 1-9. https://oi.org/10.1016/ j.jhazmat.2013.04.015

\section{Copyrights}

Copyright for this article is retained by the author(s), with first publication rights granted to the journal.

This is an open-access article distributed under the terms and conditions of the Creative Commons Attribution license (http://creativecommons.org/licenses/by/4.0/). 